able industries to the now seriously depressed sugar trade. More than a third of the population is composed of coolies from India, and this explains the importation of $50,000,000 \mathrm{lb}$. of rice annually; but as the conditions are favourable to the cultivation of rice on the spot, it is surprising that no steps have been taken to establish rice fields, if only for purposes of home consumption. The United States import bananas to the value of two millions sterling annually, but British Guiana makes no attempt to place any fruit on the market, although one shipping company offered to take 10,000 bunches of bananas every fortnight. Coffee, cacao, cocoa-nuts, cattle rearing, and other paying industries are recommended, and also the utilisation of the extensive forests for the production of valuable timber, guttapercha, indiarubber, \&c. At present the forest lands bring in a revenue of $48,000 l$. in "acre money," nearly all of which is swallowed up in the cost of collection. Under competent management these forests could be made to contribute largely to the wealth of the Colony.

But there is evidently a stubborn determination on the part of a large proportion of the colonists in the West Indies to ridicule every proposal for the introduction of new industries, and notwithstanding the ruinous experience of recent years, they insist upon regarding sugar, and sugar only, as the sole means of salvation. Any person with an open mind who attends meetings in London at which the sugar planters or their representatives discuss West Indian affairs, cannot help being struck by the general desire to leave out of consideration questions relating to subsidiary industries. Still, in spite of this unwillingness to have other things to fall back upon, subsidiary industries are making some headway, and the out-and-out supporters of sugar growing cannot but admit that this is so. At the meeting of the Royal Colonial Institute on March 8, the lecturer stated that in the four essentially English islands of Barbados, Antigua, St. Kitts and Nevis, sugar is the sole possible staple; while in the five islands, Dominica, St. Lucia, St. Vincent, Grenada and Tobago, occupied by people differing from those in the other four in language and customs, the cultivation of sugar has given place to cacao, coffee, spices, and other products. Grenada, which sixty years ago contained II 9 sugar estates, is now quite independent of sugar. Colonel Duncan has established on the island the largest and most valuable nutmeg plantation in any part of the New World. Are the misfortunes of the sugar-growing islands to be attributed to the "essentially English" character of their inhabitants?

Jamaica supplies us with a good illustration of the wisdom of selecting suitable marketable commodities for cultivation, in addition to the staple industry. As in other islands sugar was here once the one great object of cultivation, and in the year I 805 the exports were I 50,352 hogsheads of sugar and over 5,000,000 gallons of rum. Even within recent years sugar, rum, and molasses formed the bulk of the trade, for in $1881-82$ out of the total exports, valued at $1,178,594 l$., the sugar products amounted to $910,027 l$; but by $1895-96$, when the total exports had increased to nearly $1,900,000 l$., the sugar products had declined to little more than $360,000 l$. The serious depression in Jamaica dates back many years, and when it was hinted to the colonists that it would be well to introduce other cultural industries to assist in warding off the threatened crash, the idea was received with scorn and contempt. Thirty years ago Captain Bush, an American trader, began to encourage fruit growing, but for some years the venture made very slow progress, for by 1879 the fruit exports did not amount to $23,000 \%$. It was realised, however, that the time had arrived to do something to save the island, and as there were no indications of an improved sugar trade, fruit had to come to the front, and by 1889 the exports had risen to $320,323 l$., and by $1895-96$ to $536,8 \mathrm{IIl}$., three-fifths of this trade being in bananas. From this it will be gathered that the fruit trade of the island is already far more valuable than that of sugar. One of the defects of the new industry is that there is not sufficient attention given to the manner in which the various fruits should be packed for the markets, an art in which our foreign competitors excel. In addition to sugar and fruit Jamaica has under cultivation coffee, cacao, allspice, ginger, fustic, \&c., so that the entire failure of sugar would not now be anything like so disastrous as it would have been a quarter of a century ago.

All through this excellent and comprehensive report on a very difficult question, it is to be observed that the author does not propose anything with the object of hastening the end of the great sugar industry, but he recognises the necessity for supplementing, not supplanting, the staple trade by the introduction of a variety of cultural industries which would increase the wealth of the Colonies to an appreciable extent. In an appendix Dr. Morris propounds, at the request of the Chairman of the Commission, a scheme for the establishment of a Department of Economic Botany, and for agricultural instruc. tion for developing the resources of the Leeward and Windward Islands and Tobago, and for affording assistance to the experimental cane cultivation to be carried on, in continuance of present efforts, in British Guiana Barbados, and Antigua, at an estimated annual cost of $27,000 l$., a scheme which, it is hoped, will be found to be accepted by the Government when $\mathrm{Mr}$. Chamberlain brings the proposal for assistance before the House of Commons shortly.

H. H.

\section{ON THE BREEDING HABITS OF THE GREY SEAL.}

THE grey seal (Halicharus grypus) is to be met with on many parts of the British coasts, from Orkney and Shetland, throughout the Hebrides, on the north and west coasts of Ireland, and occasionally on the south and east, on the coast of Wales, in the Wash, more rarely in the Solent, and as far south as Jersey (Zoologist, 1884, p. 337); hence greater opportunities for observing it, and learning something of its habits, have occurred than has been the case with the ringed, bearded, and hooded seals. Moreover, several observers have contributed information on its breeding habits and on the conditition of the young soon after birth. The following may be cited. So long ago as I837, Mr. J. Wilson, writing on the habits of Scottish seals ( $M a g$. Zool. and Bot., i. p. 539), states that the young of the grey seal is "born above high-water mark in the end of September or beginning of October, and is at first covered with white hair, which is retained for many weeks, but shed before it takes to the water." His observations are confirmed by Edmondston, who, in his account of the seals of Shetland ("Zetland Isles," vol. ii. p. 294), remarks of the grey seal that the young are brought forth in September, October, or November. Nilsson and some other writers who have followed him have expressed the opinion that the breeding season of this species is in February; and Bell, in an attempt to explain this discrepancy ("Brit. Quad.," and edition, p. 267 ), has suggested that the milder climate of Britain permits of pairing taking place much earlier than in Scandinavia. From the united testimony, however, of other observers, there can be no doubt that this is a mistake, and that the breeding season is in the autumn. Prof. Collett, of Christiania, who some years since contributed an excellent paper on the grey seal to.the Proceedings of the Zoological Society (1881, pp. 380-87), NO. 1481 , VOL. 57] 
states that on the Fro Islands, off Trondhjem's Fiord, Norway, to which this species resorts in the breeding season, "the greater part give birth to their young in the last week of September, most usually on the 29th or 3oth, or October I-some a few days earlier and some later, but never after the middle of October." $\mathrm{He}$ adds : "The seals probably begin to breed at the age of four years, or at the earliest three years, and give birth to only one young one annually. The young seal at its birth is clothed with a wool-like covering, which falls off after the lapse of a fortnight. ... The pups pass the first three weeks of their life on land until they have shed their woolly coat, often on exactly the same spot where they have been born, and pass their time exclusively in receiving nourishment from the mother and in sleeping."

As to the length of time the woolly coat is retained, some difference of opinion has been expressed. Prof. Collett, as above stated, believes that it is shed in about a fortnight, or between a fortnight and three weeks; and he derived his information from Mr. F. Borthen, the proprietor of the Fro Islands, who furnished him on

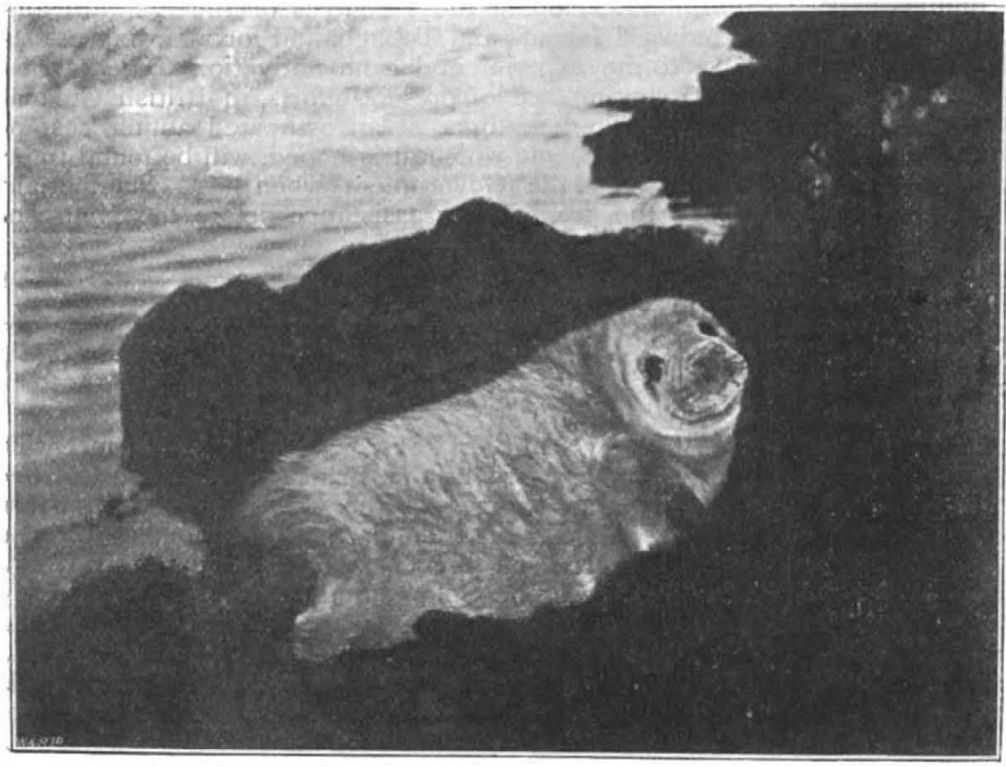

Fig. I.-Young Grey Seal shortly after birth.

several occasions with particulars concerning the seals during their stay at this group of islands. Mr. J. Wilson, already mentioned, states, somewhat vaguely, that the woolly coat is retained for many weeks. Dr. R. Ball, who furnished so much information to William Thompson, of Belfast, for his work on the natural history of Ireland, writing of the grey seal (Trans. Roy. Irish Acad, vol. viii.) has observed more precisely that the very young females are generally "of a dull yellowish white, with rather long hair which falls off in about six weeks after birth, and gives place to a shorter and more shining coat of a warm dingy yellow, variously blotched with blackish grey, the whole gradually becoming more dull, and a general dark shade spreading over the back as the animal advances in age."

On December 24, I88I, one of the Trinity pilots, whilst off the Long Sand in the Lynn Roads, saw a large seal watching over the dead carcase of a recently born young one. On attempting to capture the old one she immediately showed fight, and had to be killed before she could be secured. This animal measured seven feet in

NO. [481, VOL. 57$]$ length and five feet nine inches in girth behind the foreflippers. It was identified as a grey seal by $\mathrm{Mr}$. Thomas Southwell, of Norwich, who, in giving an account of the circumstance (Zoologist, 1882, p. 187), described the young one as being "of a beautiful silvery white, the muzzle sooty grey, a slight tinge of the same colour being visible on the back of the head, and for some distance along the spine."

The appearance presented by the young grey seal shortly after birth is well shown in the accompanying illustrations (Figs. I and 2), from photographs taken by Mr. Henry Evans, of Jura, during a visit to the Haskeir Rock in the Hebrides. Haskeir is a small rock about twelve miles west of North Uist. It is a great resort of grey seals, which breed there in October and November. It was formerly the custom with fishermen to visit this rock during the time it was frequented by the seals, and to kill them with clubs for the sake of their skins; but it is satisfactory to know, on the authority of $\mathrm{Mr}$. Henry Elwes (The Ibis, 1869, p. 25), that this practice was put a stop to some years ago by Sir John Orde, the proprietor of the island.

From the foregoing remarks it will be evident that the suggestion (p. 346) that "the white coat is not improbably shed in utero," is not borne out by the testimony of the writers quoted. Nor is it only with the grey seal that this curious state of things exists. Dr. R. Brown, writing of the seals of Greenland (Proc. Zool. Soc., 1868), states that the Greenland seal (or harp seal, as it is sometimes termed from the peculiar distribution of dark colour on the back) brings forth two young at a birth ; that the pup "retains its white woolly coat for a fortnight or three weeks, and, like the grey seal, it refuses to enter the water until this is lost." Confirmation of this is to be inferred from the remark of Prof. Collett (l.c.), that the young grey seals during the first three weeks of their lives on land are "by no means so strictly confined to a dry place of rest, as is the case with the harp seal, which, so far as we know, never enters the water voluntarily in its woolly coating."

As to the common seal (Phoca vitulina), which pairs in September, and produces a single young one-sometimes twoin the month of June, it will not be irrelevant to refer here to the condition of the young at birth. A few years ago, towards the end of May, the late Mr. A. D. Bartlett purchased of a dealer in Liverpool four adult common seals, which were carefully transported to the Zoological Gardens. On June 9, one of them gave birth to a young one, whose appearance is thus described by Mr. Bartlett (Zoologist, 1881, p. 383): "It was covered with a rather thick coat of hair; its eyes very bright and wide open; it turned and rolled about, divesting itself of the outer covering of hair, which formed a complete mat upon which the young animal lay. For the first hour or two after its birth it was very active, and within three hours after its birth was swimming and diving about in the water like an adult animal. It uttered a low soft $b a h$, or single call note, and looked about after its mother, and crawled towards her when she came out of the water. The mother would turn upon her side to let the young one suck. "The latter was 32 inches long, and weighed 20 lbs. at its birth." 
The difference between the common seal and the other species mentioned, as regards the condition of the young at birth and the shedding of the coat, is curious, and is perhaps to be accounted for in some measure by the different nature of their haunts at the time the young are born. The Greenland and grey seals bring forth their young upon rocky out-of-the-way islands, where they stand little chance of being molested, and consequently there is no need to get the young hurriedly to sea. The common seal, though breeding also on wild coasts, very often deposits the young on a sand-bank at no great distance from a fishing village, and subject sometimes to be submerged at high tides. On such banks the stay of the parent seals must be comparatively brief, for were the young not speedily able to take care of themselves, many would perish soon after birth. Thus it would seem that the greater activity of the young common seal is correlated with its conditions of life.

We have an analogous case in the difference to be found at birth in the rabbit and hare. The young rabbit born underground, where it is more or less removed from danger, is helpless and blind at birth; the young hare, deposited in a "form" on the sur-

face, where it is more exposed to enemies, is born clothed with fur and with the eyes open. The rabbit stands in no need of early or rapid development; the young hare, on the contrary, must quickly leave the nursery and learn to shift for itself. So it may be with the seals.

\section{J. E. HARTING.}

\section{SIR RICHARD QUAIN.}

SIR RICHARD QUAIN, Bart.,

M.D., F.R.C.P., F.R.S., President of the General Medical Council, died on March I3, at the advanced age of eighty-one years. He had been ill for more than twelve months, and during the last half-year of his life was entirely confined to bed. His last appearance in public was when his paper on the "Cause of the First Sound of the Heart" was read before the Royal Society in June, on which occasion the President made a touching reference to the extraordinary courage which Quain displayed. His life had been one of ceaseless activity, good health, and overflowing spirits ; and when overtaken by disease he appeared not to regard or understand rest, physician though he was. The paper just referred to was written in bed, and he left his bed to present and defend it. But no one was surprised at this who knew the story of the man's life.

Richard Quain was an Irishman, born at Mallow, Co. Cork, on October 30, 1816. As a child he was precocious. $\mathrm{He}$ was thoroughly grounded in English and the classics: distinguished himself at the public examinations, and at fifteen entered on an apprenticeship of five years as an apothecary. Even at this age he resolutely fought the cholera when it swept over Limerick. No doubt experience of this kind, and thus early, gave Quain courage and readiness in dealing with disease as a practitioner; but influences of more scientific bearing were to shape his career. The year 1837 finds him in London at University College, with a galaxy of teaching talent around him: Sharpey, Graham, Grant, Elliotson, Jones Quain the anatomist, and Richard Quain the surgeon and author of "The Arteries"-his cousins, from the same district-and as an instructor in practical surgery the great

$$
\text { No. I48I, voL. 57] }
$$

Liston, with whom Quain came to be on terms of intimate friendship. The clever young Irish lad, enjoying such advantages, immediately made his way to the front at College and University; and at the end of his curriculum as a student, obtained the coveted post of Resident Medical Officer at the Hospital.

It was shortly after this that Quain produced the brilliant research on the nature of fatty degeneration with which his name is associated for all time, and established his reputation as an original observer and thinker. Simple as the doctrine appears to us at the present day, fifty years ago it was a startling pronouncement by a young man fresh from his medical studies that fat may be, and often is, a product of the decomposition of muscular tissue, and that this change goes on in the living body. The ideas of life, nutrition, and death were greatly influenced by the doctrine. This, let us remember, was many years before Bauer and Voit, working with phosphorus in starving animals, furnished the proof experimentally and quantitatively; and Quain's claim was freely admitted by Virchow and Paget.

Although he was one of the founders of the Patho 